\title{
ANALISIS PENGARUH PROFITABILITAS, LEVERAGE DAN UKURAN PERUSAHAAN TERHADAP INCOME SMOOTHING
}

\author{
Nurrindi Mustika Sari ${ }^{(1)}, \operatorname{Rudy}^{(2) *}$ \\ ${ }^{1,2}$ Alumni dan Dosen Akuntansi, STIE Bisnis Indonesia, Jakarta Barat, \\ Indonesia
}

*Corresponding author's e-mail: rudy@stiebi.ac.id

\begin{abstract}
Abstrak. Penelitian ini bertujuan untuk mengetahui analisis pengaruh profitabilitas, leverage, dan ukuran perusahaan terhadap income smoothing. Data sekunder yang dikumpulkan dari perusahaan-perusahaan pertambangan yang terdaftar di Bursa Efek Indonesia pada tahun 2013-2018. Metode yang digunakan adalah metode deskriptif kuantitatif. Sampel ditentukan berdasarkan metode purposive sampling, sebanyak 36 laporan keuangan. Teknis analisis data menggunakan regresi logistik yang diolah menggunakan bantuan progam SPSS versi 25 . Hasil yang diperoleh dari penelitian ini menjelaskan bahwa terdapat 13 laporankeuangan perusahaan pertambangan dari 36 sampel melakukan income smoothing. Profitabilitas dan Ukuran Perusahaan tidak berpengaruh secara signifikan terhadap income smoothing dan Leverage berpengaruh secara signifikan terhadap income smoothing.
\end{abstract}

Kata Kunci: profitabilitas, leverage, ukuran perusahaan, income smoothing.

\section{PENDAHULUAN}

\subsection{Latar Belakang}

Persaingan di dunia bisnis yang semakin ketat dan situasi perekonomian negara yang tidak menentu mendorong manajemen untuk bekerja lebih efektif dan efisien agar perusahaan mampu bertahan dan menjaga eksistensinya sekaligus meningkatkan kinerja manajemen perusahaan untuk mendapatkan keuntungan yang optimal (Hardaningtyas \& Siswoyo, 2016). Laba merupakan salah satu alat untuk mengukur kinerja manajemen, membantu mengestimasi kemampuan laba yang representatif dalam jangka panjang, dan menaksir risiko investasi atau meminjamkan dana. Investor beranggapan apabila laba perusahaan dari suatu periode ke periode berikutnya stabil, menandakan kinerja manajemen bagus sehingga akan memberikan rasa aman untuk para 
investor dalam menginvestasikan uangnya. Hal ini mendorong manajemen untuk melakukan tindakan yang tidak semestinya (disfunctional behaviour), yaitu manajemen laba (earning management) dan salah satu bentuknya adalah tindakan perataan laba (income smoothing) (Handayani \& Fuad, 2015).

Income smoothing merupakan salah satu cara manajemen untuk mengelola laba yang merepresentasikan keadaan perusahaan. Income smoothing dapat diartikan juga sebagai pengurangan fluktuasi laba yang dihasilkanperusahaan dari tahun ke tahun dengan memindahkan pendapatan yang tinggike periode-periode yang kurang menguntungkan.Income smoothing dilakukan dengan cara memperkecil atau memperbesar jumlah laba suatu periode mendekati jumlah laba periode sebelumnya (Pradana \& Sunaryo, 2012). Namun, income smoothing bukan digunakan untuk membuat laba suatu periode sama dengan laba periode sebelumnya karena dalam mengurangi fluktuasi laba juga perlu dipertimbangkan tingkat pertumbuhan normal yang diharapkan pada periode tersebut. Praktik income smoothing merupakan fenomena yang umum terjadi di banyak negara, dan sering kali dilakukan dengan sengaja sehingga menyebabkan pengungkapan laba yang mengakibatkan para investor dan kreditur tidak memperoleh informasi yang akurat, dan memadai untuk mengevaluasi hasil dan risiko portofolionya. Praktik income smoothing sudah tidak asing lagi bagi setiap perusahaan, akan tetapi sulit untuk dideteksi dan para pengguna informasi tersebut tidak menyadari akan adanya praktik perataan laba di dalam laporan keuangan setiap perusahaan, maka dapat menyebabkan kesalahan dalam pengambilan keputusan (Siti Masyithoh, 2017).

Profitabilitas juga digunakan untuk mengukur seberapa besar tingkat laba yang dihasilkan oleh perusahaan, semakin tinggi tingkat profitabilitas maka semakin baik kinerja manajemen dalam mengelola suatu perusahaan, sedangkan perusahaan dengan tingkat profitabilitas yang rendah akan cenderung untuk melakukan income smoothing atau perataan laba dibandingkan perusahaan dengan profitabilitas tinggi. Income smoothing dilakukan agar fkuktuasi laba yang dihasilkan perusahaan terlihat lebih stabil, laba yang rata dapat menunjukkan bahwa perusahaan memiliki kinerja yang baik walaupun profitabilitasnya rendah.

Penggunaan utang akan menentukan tingkat leverage perusahaan karena dengan menggunakan lebih banyak utang dibandingkan modal sendiri maka beban tetap yang ditanggung perusahaan tinggi yang pada akhirnya akan menyebabkan profitabilitas menurun. Semakin besar utang perusahaan maka semakin besar risiko yang dihadapi investor, dan investor akan cenderung meminta tingkat laba yang semakin tinggi. Akibat kondisi tersebut perusahaan cenderung untuk melakukan praktik income smoothing. Leverage dapat diartikan sebagai penggunaan aktiva suatu dana. Semakin besar leverage menunjukkan bahwa dana yang 
disediakan oleh pemilik dalam membiayai investasi perusahaan semakin kecil, atau tingkat penggunaan utang yang dilakukan perusahaan semakin meningkat. Rasio utang dapat digunakan agar dapat menilai sejauh mana perusahaan menggunakan uang yang dipinjam (Damayanti, Ambarwati, \& Susilawati, 2019). Penggunaan leverage dalam perusahaan bisa saja meningkatkan laba perusahaan, tetapi bila terjadi sesuatu yang tidak sesuai harapan, maka perusahaan dapat mengalami kerugian yang sama dengan persentase laba yang diharapkan, bahkan mungkin saja lebih besar.

Ukuran perusahaan adalah suatu skala dimana dapat diklasifikasikan besar kecil perusahaan. Salah satu cara yang dapat digunakan adalah logaritma natural dari total aset. Pada dasarnya ukuran perusahaan terbagi dalam 3 (tiga) kategori yaitu perusahaan besar, perusahaan menengah, dan perusahaan kecil (Musdholifah \& Puspitasari, 2009). Penentuan ukuran perusahaan ini didasarkan kepada total asset perusahaan. Perusahaan-perusahaan yang lebih besar memiliki dorongan yang lebih besar pula untuk melakukan income smoothing dibandingkan dengan perusahaan-perusahaan yang lebih kecil karena perusahaanperusahaan yang lebih besar menjadi subjek pemeriksaan (pengawasan yang lebih ketat dari pemerintah dan masyarakat umum / general public) sehingga ukuran perusahaan besar lebih memilih untuk melakukan income smoothing, karena kenaikan laba yang fluktuasinya terlalu tinggi akan menyebabkan pajak yang tinggi pula bagi perusahaan, dan jika laba perusahaan mengalami penurunan secara drastis maka investor akan beranggapan perusahaan mengalami krisis.

Beberapa fenomena perusahaan besar yang telah melakukan perataan laba (income smoothing) antara lain: (1) Menurut Rilis Berita dari https://economy.okezone.com/, PT Timah (Persero), Tbk (TINS) pada tahun 2015 memberikan informasi kondisi keuangan perusahaan yang berbeda kepada publik dari yang sebenarnya terjadi, dimana sejak tahun 2013 direksi PT Timah (Persero), Tbk (TINS) menurut Ikatan Karyawan Timah (IKT) yang berasal dari Provinsi Bangka Belitung dan Kepulauan Riau telah banyak melakukan kesalahan dan kelalaian semasa menjabat selama tiga tahun sejak 2013 lalu, yaitu dengan memberikan informasi yang berbeda kepada publik mengenai pencapaian kondisi keuangan perusahaan sehingga mereka menilai direksi telah banyak melakukan kebohongan publik melalui media. Contohnya adalah pada press release laporan keuangan semester I-2015 yang mengatakan bahwa efisiensi dan strategi yang telah membuahkan kinerja yang positif. Padahal kenyataannya pada semester I-2015 laba operasi rugi sebesar Rp59 miliar, hal ini dilakukan tentu agar kinerja perusahaan dinilai baik oleh publik sehingga dapat menarik minat investor pada perusahaan. Sebagai informasi, selain mengalami penurunan laba, PT Timah juga mencatatkan peningkatan utang hampir 100 persen dibanding 2013. Pada tahun 2013, 
utang perseroan hanya mencapai Rp263 miliar. Namun, jumlah utang ini meningkat hingga Rp2,3 triliun pada tahun 2015 (Afrianto, 2016); (2) Menurut rilis berita dari https://investasi.kontan.co.id/, portofolio investasi PT Saratoga Investama Sedaya, Tbk (SRTG) pada tahun 2016 semester I mengalami pertumbuhan sebesar $26 \%$ dari Rp13,6 triliun pada 31 Desember 2015 menjadi Rp17,1 triliun pada 30 Juni 2016. Pertumbuhan portofolio itu terutama diperoleh dari peningkatan nilai pasar dari investasi Perseroan di sektor sumber daya alam serta didukung oleh kinerja kuat dan berkelanjutan perusahaan investasi di sektor infrastruktur dan konsumer. Mulai semester I tahun 2016, Saratoga telah menerapkan "Pernyataan Standar Akuntansi Keuangan (PSAK) 65: Pengecualian Konsolidasi" dalam pelaporan kinerja keuangan Perseroan. PSAK 65 tersebut memungkinkan Saratoga untuk menerapkan nilai wajar atas aset-aset investasinya. Oleh karena perubahan ini diterapkan secara prospektif (berlaku ke depan), metodologi penilaian wajar tersebut memberikan gambaran yang lebih jelas terhadap kinerja Saratoga sebagai perusahaan investasi aktif. Direktur Keuangan Saratoga Jerry Ngo menambahkan perubahan dalam penyajian laporan keuangan ini dilakukan atas dasar pertimbangan yang matang untuk dapat menyajikan laporan keuangan yang lebih jelas dan akurat. Melalui penyajian laporan akuntansi, Saratoga tercatat berhasil membukukan laba bersih yang distribusikan kepada pemegang saham sebesar $R p 4,8$ triliun. Ini mencakup keuntungan sebesar Rp2,2 triliun yang sebagian besar sebagai akibat dari perubahan penyajian pelaporan keuangan dan Rp2,6 triliun dan sebagian besar dikontribusikan dari peningkatan nilai pasar atas investasi PT Saratoga di Adaro Energy dan Tower Bersama (Dikky Setiawan, 2016); dan (3) Menurut rilis berita dari https://finance.detik.com/ bahwa GIAA mencatatkan laba bersih pada perolehan laba bersih perusahaan tahun 2018 yang dianggap janggal sebesar US\$809,85 ribu atau setara Rp11,33 miliar (kurs Rp 14.000). Laba tersebut disebabkan oleh melambungnya pendapatan usaha lainnya yang totalnya mencapai US\$306,88 juta. Ternyata ada dua komisaris yang tidak mau menandatangani laporan keuangan itu. Mereka merasa keberatan dengan pengakuan pendapatan atas transaksi Perjanjian Kerja Sama Penyediaan Layanan Konektivitas Dalam Penerbangan, antara PT Mahata Aero Teknologi dan PT Citilink Indonesia. Pengakuan tersebut dianggap tidak sesuai dengan kaidah Pernyataan Standar Akuntansi Keuangan (PSAK) nomor 23, dimana manajemen Garuda Indonesia mengakui pendapatan dari PT Mahata sebesar US\$239.940.000, dimana sebesar US\$28.000.000 merupakan bagian dari bagi hasil yang diperoleh dari PT Sriwijaya Air. Padahal uang itu masih dalam bentuk piutang, namun diakui perusahaan masuk dalam pendapatan. Namun pemegang saham terbesar yakni Pemerintah berpandangan sebaliknya. Mereka menyetujui laporan keuangan tersebut (Sugianto, 2019). 
Berdasarkan beberapa fenomena yang telah diuraikan di atas menunjukkan bahwa praktik perataan laba masih banyak dilakukan oleh beberapa perusahaan di Indonesia. Penelitian ini melibatkan 3 (tiga) faktor yang meliputi profitabilitas, leverage, dan ukuran perusahaan yang digunakan untuk mengidentifikasi faktor-faktor yang mempengaruhi indeks income smoothing.

\subsection{Tujuan Khusus Penelitian}

Penelitian ini bertujuan untuk membuktikan secara empiris bahwa profitabilitas, leverage, dan ukuran perusahaan merupakan faktor-faktor yang mendorong terjadinya dan mempengaruhi praktik income smoothing pada perusahaan sektor pertambangan yang terdaftar di Bursa Efek Indonesia periode 2013 sampai 2018.

\section{TINJAUAN PUSTAKA}

Profitabilitas adalah salah satu rasio yang memiliki tujuan dan manfaat bagi pihak eksternal perusahaan. Jenis-jenis rasio profitabilitas yang lazim digunakan dalam praktik untuk mengukur kemampuan perusahaan dalam menghasilkan laba: (1) Hasil pengembalian atas aset merupakan rasio yang menunjukkan seberapa besar kontribusi aset dalam menciptakan laba bersih (ROA); (2) Hasil pengembalian atas ekuitas merupakan rasio yang menunjukkan seberapa besar kontribusi ekuitas dalam menciptakan laba (ROE); (3) Margin laba kotor merupakan rasio yang digunakan untuk mengukur besarnya persentase laba kotor atas penjualan bersih (GPM); (4) Margin laba operasional merupakan rasio yang digunakan untuk mengukur besarnya persentase laba operasional atas penjualan bersih (OPM); (5) Margin laba bersih merupakan rasio yang digunakan untuk mengukur besarnya persentase laba bersih atas penjualan bersih (NPM) (Hery, 2016, hal. 193); dan (6) Perhitungan yang berdasarkan keuntungan usaha yang dihasilkan oleh nasabah dengan return kepada investor berupa feedback rate tidak hanya berdasarkan pendapatan atau penjualan (Yanti, 2018).

Tujuan penggunaan rasio profitabilitas bagi perusahaan maupun pihak luar perusahaan yaitu: (1) mengukur atau menghitung laba yang diperoleh perusahaan dalam satu periode tertentu; (2) menilai posisi laba perusahaan tahun sebelumnya dengan tahun sekarang; (3) menilai perkembangan laba dari waktu ke waktu; dan (4) menilai besarnya laba bersih sesudah pajak dengan modal sendiri (Kasmir, 2016, hal. 196).

$$
\text { Hasil Pengembalian atas Aset }=\frac{\text { Laba Bersih }}{\text { Total Aset }}
$$

(Hery, 2016, hal. 93) 
Leverage adalah kemampuan perusahaan untuk membayar seluruh kewajibannya, baik jangka pendek maupun jangka panjang apabila perusahaan dibubarkan (dilikuidasi) (Kasmir, 2016, hal. 151), artinya berapa besar beban utang yang ditanggung perusahaan dibandingkan dengan asetnya. Analisis rasio leverage, perusahaan akan mengetahui beberapa hal berkaitan dengan penggunaan modal sendiri dan modal pinjaman serta mengetahui rasio kemampuan perusahaan untuk memenuhi kewajibannya. Setelah diketahui, manajer keuangan dapat mengambil kebijakan yang dianggap perlu guna menyeimbangkan penggunaan modal. Akhirnya, dengan rasio ini kinerja manajemen selama ini akan terlihat apakah sesuai tujuan perusahaan atau tidak.

Rasio Utang terhadap Total Aset (Debt to Asset Ratio), yaitu rasio digunakan untuk mengukur perbandingan antara total utang dengan total aset. Dengan kata lain, rasio ini digunakan untuk mengukur seberapa besar aset perusahaan dibiayai oleh utang atau seberapa besar utang perusahaan berpengaruh terhadap pembiayaan aset. Berikut adalah rumus yang digunakan untuk menghitung rasio utang:

Rasio Utang $=\frac{\text { Total Utang }}{\text { Total Aset }}$

(Hery, 2016, hal. 166)

Ukuran perusahaan adalah suatu skala untuk mengklasifikasikan besar kecilnya suatu perusahaan dengan menggunakan berbagai cara, antara lain dengan total aset, total penjualan, nilai pasar saham, dan sebagainya (Hery, 2016, hal. 3). Ukuran perusahaan pada dasarnya dibagi atas tiga kategori, yaitu perusahaan besar, perusahaanmenengah dan perusahaan kecil (Herlina, 2017, hal. 613).

Tabel 1. Kriteria Ukuran Perusahaan

\begin{tabular}{|c|c|c|}
\hline \multirow[b]{2}{*}{$\begin{array}{c}\text { Ukuran } \\
\text { Perusahaan }\end{array}$} & \multicolumn{2}{|l|}{ Kriteria } \\
\hline & $\begin{array}{c}\text { Assets } \\
\text { (Tidak termasuk tanah dan bangunan } \\
\text { tempat usaha) }\end{array}$ & Penjualan Tahunan \\
\hline Usaha Mikro & Maksimal 50 juta & Maksimal 300 juta \\
\hline Usaha Kecil & $>50$ juta-500 juta & $>300$ juta-2,5 M \\
\hline $\begin{array}{c}\text { Usaha } \\
\text { Menengah }\end{array}$ & $>10$ juta-10 M & $>2,5 \mathrm{M}-50 \mathrm{M}$ \\
\hline Usaha Besar & $>10 \mathrm{M}$ & $>50 \mathrm{M}$ \\
\hline
\end{tabular}

Kriteria di atas menunjukkan bahwa ukuran perusahaan besar memiliki asset (tidak termasuk tanah dan bangunan tempat usaha) lebih dari sepuluh miliar rupiah dengan penjualan tahunan lebih dari lima puluh miliar rupiah (UU, 2008). Ukuran perusahaan yang diwakili oleh total aktiva dan total pendapatan perusahaan dengan komposisi 60:40 
(Prasidhanto, 2012, hal. 35). Ukuran perusahaan diukur dengan logaritma natural dari total aktiva suatu perusahaan. Ukuran perusahaan dihitung dengan rumus sebagai berikut:

\section{Ukuran Perusahaan = Ln Total Aktiva}

(Supriastuti \& Warnanti, 2015)

Perataan laba atau income smoothing dapat dicapai dengan 2 (dua) jenis, yaitu: (1) Real smoothing adalah perataan laba yang dilakukan melalui transaksi keuangan sesungguhnya dengan mempengaruhi laba melalui perubahan dengan sengaja atas kebijakan operasi; dan (2) Artificial smoothing atau sering juga disebut accounting smoothing, yaitu perataan laba melalui prosedur akuntansi yang diterapkan untuk memindahkan biaya dan/atau pendapatan dari suatu periode ke periode lain (Hery, Pengendalian Akuntansi dan Manajemen, 2014, hal. 8-9). Perataan laba atau income smoothing hanya merupakan salah satu aspek dalam rekayasa laba. Perataan laba atau income smoothing diartikan sebagai suatu pengurangan dengan sengaja atas fluktuasi laba yang dilaporkan supaya berada pada tingkat yang dianggap normal bagi perusahaan. Perataan laba ini sering dilakukan dengan tujuan (di antaranya) supaya menjadi lebih mudah dalam mendapatkan pinjaman kreditur dan menarik investor (Hery, Pengendalian Akuntansi dan Manajemen, 2014, hal. 8).

Aktivitas income smoothing ini, walaupun harus diungkapkan dalam laporan keuangan, bukan hal yang mudah untuk dideteksi dan terdeteksi. Ada kecenderungan pemakai laporan keuangan yang hanya melihat bottom line dari informasi keuangan itu tanpa mau bersusah payah mempelajari dan memahami pelaporan keuangan (financial reporting) secara integral dan komprehensif. Padahal keuangan hanya akan bisa "berbicara" jika pemakainya memahami seluruh informasi yang disajikan dalam pelaporan keuangan itu (Sulistyanto, 2014, hal. 42).

Tindakan income smoothing diuji dengan indeks Eckel yang menggunakan Coefficient Variation (CV) variabel penghasilan dan variabel penjualan bersih. Praktik income smoothing diukur dengan menggunakan indeks income smoothing, yaitu Indeks Eckel dikarenakan Indeks Eckel dapat menunjukkan adanya praktik income smoothing yang dilakukan oleh perusahaan sehingga dapat membedakan antara perusahaan yang melakukan praktik income smoothing dengan perusahaan yang tidak melakukan praktik income smoothing (Hastria, Rasuli, \& Nurazlina, 2014, hal. 7).

\footnotetext{
Indeks Income Smoothing $=\frac{\mathrm{CV} \Delta \mathrm{I}}{\mathrm{CV} \Delta \mathrm{S}}$

Keterangan:

$\Delta \mathrm{I}=$ Perubahan laba dalam satu periode

$\Delta S=$ Perubahan penjualan dalam satu periode

$\mathrm{CV}=$ Koefisien variasi dari variabel yaitu standar deviasi dibagi dengan nilai 
yang diharapkan

Apabila $\mathrm{CV} \Delta \mathrm{I}>\mathrm{CV} \Delta \mathrm{S}$ maka perusahaan tidak digolongkan sebagai perusahaan yang melakukan tindakan income smoothing. Untuk mengetahui adanya praktik income smoothing yang dilakukan oleh perusahaan akan menunjukkan $\mathrm{CV} \Delta \mathrm{I}<\mathrm{CV} \Delta \mathrm{S}$ atau sebaliknya untuk bukan income smoothing, atau dengan kata lain bahwa perusahaan yang melakukan income smoothing akan mempunyai indeks lebih kecil dari satu $(<1)$ dan sebaliknya untuk yang tidak melakukan income.

Kerangka Pemikiran

X1. Profitabilitas

$\mathrm{X} 2$. Leverage

X3. Ukuran Perusahaan

\section{INCOME SMOOTHING}

Gambar 2. Model Penelitian

Hipotesis Penelitian

H1 = Profitabilitas berpengaruh signifikan terhadap Income Smoothing

$\mathrm{H} 2$ = Leverage berpengaruh signifikan terhadap Income Smoothing

$\mathrm{H} 3$ = Ukuran Perusahaan berpengaruh signifikan terhadap Income

Smoothing

\section{METODE PENELITIAN}

\subsection{Subjek penelitian}

Subjek dalam penelitian ini adalah perusahaan sektor pertambangan yang terdaftar di Bursa Efek Indonesia (BEI) sejak tahun 2013-2018.

\subsection{Jenis dan sumber data}

Jenis data terbagi 2 (dua) yaitu data primer dan data. Penelitian ini menggunakan data sekunder yaitu data yang diperoleh dari sumber sekunder, misalnya, catatan atau dokumentasi perusahaan, publikasi pemerintah, analisis industri yang diberikan oleh media, web, internet dan lainnya (Sekaran \& Bougie, 2017, hal. 130). Sumber data yang digunakan yaitu laporan tahunan dan laporan keuangan perusahaan yang diakses langsung melalui www.idx.co.id atau website resmi perusahaan.

\subsection{Populasi dan Sampel Penelitian}

Populasi dalam penelitian ini adalah 47 perusahaan sektor pertambangan yang listing di Bursa Efek Indonesia. Teknik pemilihan sampel menggunakan metode purposive sampling dengan kriteria: (1) perusahaan sektor pertambangan yang memperoleh laba setiap tahunnya dari tahun 2013 sampai dengan tahun 2018; dan (2) Perusahaan sektor pertambangan 
yang memiliki kelengkapan data yang dibutuhkan dalam penelitian selama periode 2013-2018.

Tabel 2. Sampel Terpilih

\begin{tabular}{ccc}
\hline Kode & Nama Perusahaan & Tanggal IPO \\
Emiten & PT Ratu Prabu Energi, Tbk. & 30-April-2003 \\
\hline ARTI & PT Citatah, Tbk. & 03-Juli-1996 \\
CTTH & PT Elnusa, Tbk. & 06-Feb-2008 \\
ELSA & PT Bukit Asam (Persero), Tbk. & 23-Des-2002 \\
PTBA & 12-Jul-2006 \\
RUIS & PT Radiant Utama Interinsco, Tbk. & 19-Okt-1995 \\
TINS & PT Timah (Persero), Tbk. & 6 \\
\hline
\end{tabular}

(Sumber: Data BEI, 2019)

\subsection{Metode Analisis Data}

Metode analisis data dalam penelitian ini menggunakan teknik logistic regression dengan pengolahan data dengan bantuan program SPSS (Stastistical Package for Social Science) versi 25. Analisis regresi bertujuan untuk menjelaskan atau memodelkan hubungan antar variabel, dimana terdapat variabel y sebagai variabel respons, output, tak bebas, atau variabel yang dijelaskan, dan variabel $x$ sebagai variabel prediktor, masukan, bebas, atau variabel penjelas (Kurniawan \& Yuniarto, 2016, hal. 22).Model regresi logistik yang digunakan karena variabel dependen yang digunakan berbentuk dikotomik/biner, yakni variabel yang hanya memiliki 2 (dua) kategori nilai 0 atau nilai 1.

Adapun persamaan regresi logistik dirumuskan sebagai berikut:

$$
\operatorname{Ln}(\mathrm{P} / 1-\mathrm{P})=\alpha+\beta 1 . R O A+\beta 2 . \mathrm{DR}+\beta 3 \text {. LNASET }+\mathrm{è}
$$

Keterangan:

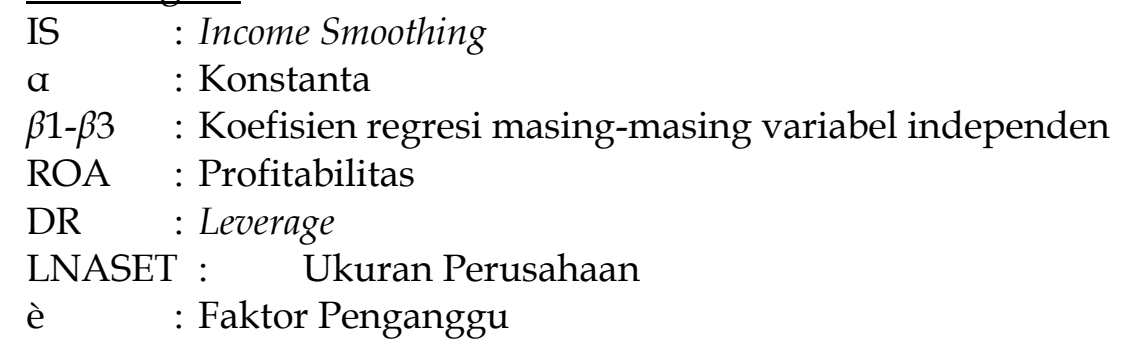

\section{Hasil dan Pembahasan}

\subsection{Statistik Deksriptif}

Tabel 3 Statistik Deskriptif Variabel Penelitian

\begin{tabular}{|l|r|r|r|r|r|}
\hline \multicolumn{7}{|c|}{ Descriptive Statistics } \\
& & & & & \multicolumn{1}{c|}{$\begin{array}{c}\text { Std. } \\
\text { Deviation }\end{array}$} \\
\hline ROA & $\mathrm{N}$ & Minimum & Maximum & Mean &, 05677 \\
\hline
\end{tabular}




\begin{tabular}{|l|r|r|r|r|r|}
\hline DR & 36 &, 30 &, 80 &, 4829 &, 14123 \\
\hline LNASET & 36 & 15,25 & 28,62 & 21,8607 & 5,96823 \\
\hline IS & 36 &, 00 & 1,00 &, 3611 &, 48714 \\
\hline Valid N (listwise) & 36 & & & & \\
\hline
\end{tabular}

(Sumber: Output SPSS 25.00, 2019)

Hasil statistif deksriptif menunjukkan bahwa nilai $\mathrm{N}=36$ adalah jumlah observasi, minimum adalah nilai terendah dari rangkaian pengamatan, maximum adalah nilai tertinggi dari rangkaian pengamatan, mean adalah hasil penjumlahan seluruh data dibagi dengan banyaknya data, dan standar deviasi adalah akar dari jumlah kuadrat dari selisih nilai data dengan rata-rata dibagi banyaknya data.

Hasil penelitian analisis statistik deskriptif menunjukkan bahwa variabel profitabilitas yang diproksikan dengan Return On Asset memiliki nilai minimum 0,00 menunjukkan bahwa nilai terendah profitabilitas dari seluruh pengamatan sebesar 0,00 dan maksimum 0,23 artinya dari seluruh pengamatan nilai tertinggi profitabilitias mengalami laba positif sebesar 23 persen. Rata-rata (mean) sebesar 0,0537, angka ini menunjukan bahwa rata-rata perusahaan memiliki kemampuan menghasilakn laba positif sebesar 5,37 persen atas kepemilikan aset dengan nilai standar deviasi sebesar 0,05677 artinya variasi data sampel pengamatan selama periode tersebut memiliki deviasi yang cukup tinggi (nilai mean dibandingkan dengan standar deviasi mendekati angka 1).

Variabel Leverage yang diproksikan dengan debt ratio memiliki nilai minimum 0,30 dan maksimum 0,80 dengan rata-rata (mean) sebesar 0,4829 dan deviasi standar 0,14123. Artinya seluruh total aset yang diperoleh perusahaan dalam periode 6 tahun terakhir yaitu 2013-2018, 48,29 persen dibiayai dengan utang dan variasi data sampel pengamatan selama periode tersebut juga memiliki deviasi yang sangat tinggi (nilai mean dibandingkan dengan standar deviasi lebih besar dari 1).

Variabel Ukuran Perusahaan memiliki nilai minimum 15,25 dan maksimum 28,62 dengan rata-rata (mean) sebesar 21,8607 dan deviasi standar 5,96823. Artinya rata-rata perusahaan sampel penelitian ini memiliki nilai log natural total aset sebesar 21,8607 atau memiliki rata-rata total aset sebesar Rp3.118.755.871,16 dan variasi data sampel pengamatan selama periode tersebut juga memiliki deviasi yang sangat tinggi (nilai mean dibandingkan dengan standar deviasi lebih besar dari 1).

Variabel Income smoothing pada perusahaan pertambangan yang terdaftar di BEI tahun 2013-2018 memiliki nilai minimum 0,00 dan maksimum 1,00 dengan rata-rata (mean) sebesar 0,3611 dan deviasi standar 0,48714. Artinya laporan keuangan yang manjadi sampel penelitian 36,11 persen melakukan perataan laba atau income smoothing dan variasi data sampel pengamatan selama periode tersebut juga memiliki deviasi yang cukup tinggi (nilai mean dibandingkan dengan standar 
deviasi mendekati angka 1). Distribusi income smoothing dapat dilihat pada tabel berikut ini.

Tabel 4 Frekuensi Income Smoothing

\begin{tabular}{|c|l|r|r|r|r|}
\hline \multicolumn{7}{|c|}{ IS } \\
\hline \multirow{3}{|c|}{ Valid } & Frequency & Percent & Valid Percent & Cumulative Percent \\
\cline { 2 - 6 } &, 00 & 23 & 63,9 & 63,9 & 63,9 \\
\cline { 2 - 6 } & 1,00 & 13 & 36,1 & 36,1 & 100,0 \\
\cline { 2 - 6 } & Total & 36 & 100,0 & 100,0 & \\
\hline
\end{tabular}

(Sumber: Output SPSS 25.00, 2019)

Perusahaan mempublikasikan laporan keuangan 13 atau 36,11 persen melakukan tindakan income smoothing dan 23 laporan keuangan atau 63,9 persen tidak melakukan tindakan income smoothing atau perataan laba.

4.2. Uji Kelayakan Model

Tabel 5 Hasil Uji Hosmer dan Lemeshow's Goodness of Fit Test

\begin{tabular}{|l|r|r|r|}
\hline \multicolumn{5}{|c|}{ Hosmer and Lemeshow Test } \\
\hline Step & Chi-square & df & Sig. \\
\hline 1 & & 7,715 & 712 \\
\hline
\end{tabular}

(Sumber: Output SPSS 25.00, 2019)

Model mampu memprediksi nilai observasinya dan dapat dikatakan model dapat diterima jika nilai Hosmer dan Lemeshow's Goodness of Fit Test $>0,05$. Hasil output SPSS 25.00 menunjukkan bahwa besarnya nilai statistik Chi-Square Hosmer dan Lemeshow's Goodness of Fit sebesar 3,715 dengan probabilitas signifikansi 0,812 yang nilainya lebih besar daripada a $(0,05)$ dengan demikian dapat disimpulkan bahwa model fit dan dapat diterima, serta mampu memprediksi nilai observasinya atau dapat dikatakan model dapat diterima karena cocok dengan data observasinya. Untuk memperjelas gambaran penjelasan ketepatan model regresi logistik dapat dilihat pada tabel klasifikasi berikut ini.

Tabel 6 Klasifikasi

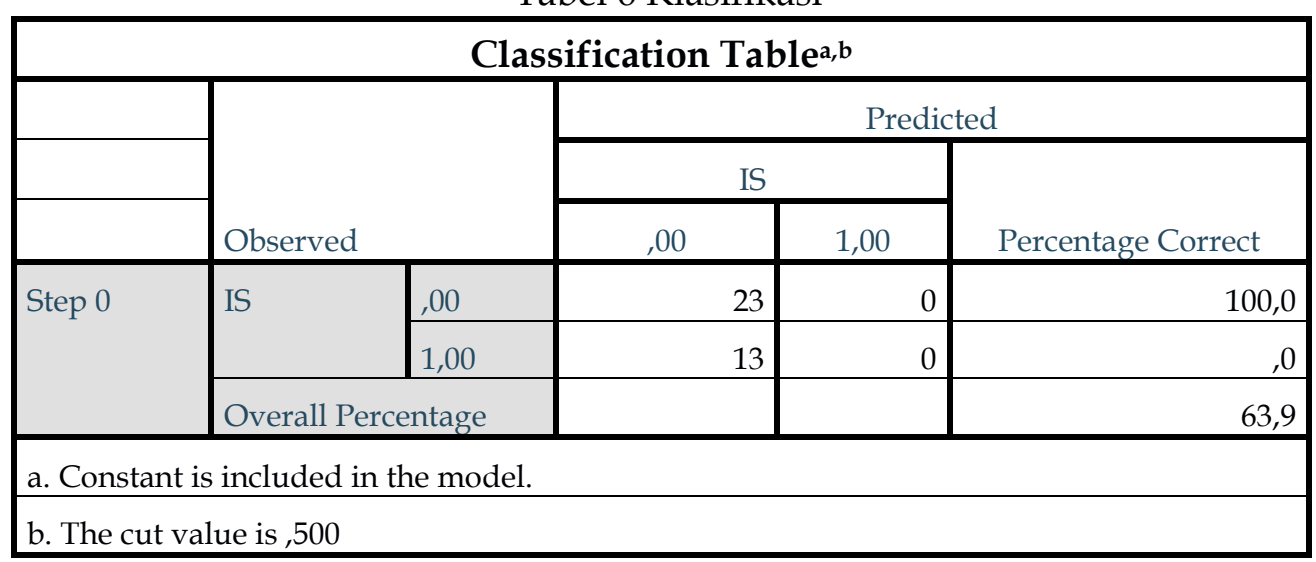

(Sumber: Output SPSS 25.00, 2019) 
Tabel klasifikasi menyajikan 36 laporan keuangan yang terdiri 6 perusahaan yang tidak melakukan tindakan income smoothing pada laporan keuangan $(0,00)$ sebanyak 23 laporan keuangan, sedangkan dari 13 laporan keuangan yang termasuk melakukan tindakan income smoothing $(1,00)$. Dengan demikian secara keseluruhan dari 36 perusahaan ada 63,9 persen yang dapat diprediksikan dengan tepat oleh model logistic ini. Tingginya persentase ketepatan tabel klasifikasi tersebut mendukung tidak adanya perbedaan yang signifikan terhadap data hasil prediksi dan data observasinya yang menunjukkan sebagai model regresi yang baik. Setelah melakukan pengujian kelayakan model regresi yang digunakan, maka langkah selanjutnya adalah menilai keseluruhan model (overall model fit) dengan membandingkan nilai -2 log likelihood (LL) pada masing-masing block number.

Tabel 7 Hasil Uji Perbandingan Nilai -2 Log Likelihood

\begin{tabular}{|c|c|c|c|c|c|c|}
\hline \multicolumn{7}{|c|}{ Iteration History $^{a, b, c, d}$} \\
\hline \multirow{2}{*}{\multicolumn{2}{|c|}{ Iteration }} & \multirow{3}{*}{\begin{aligned} \multicolumn{2}{l}{$\begin{array}{l}-2 \log \\
\text { likelihood }\end{array}$} \\
35,488 \\
\end{aligned}} & \multicolumn{4}{|c|}{ Coefficients } \\
\hline & & & Constant & $\mathrm{ROA}$ & DR & LNASET \\
\hline \multirow[t]{6}{*}{ Step 1} & 1 & & $-4,218$ & $-3,762$ & 5,551 &, 054 \\
\hline & 2 & 34,537 & $-4,602$ & $-9,317$ & 6,672 & , 052 \\
\hline & 3 & 34,431 & $-4,410$ & $-13,045$ & 6,839 &, 045 \\
\hline & 4 & 34,428 & $-4,368$ & $-13,792$ & 6,861 & , 043 \\
\hline & 5 & 34,428 & $-4,367$ & $-13,814$ & 6,861 & , 043 \\
\hline & 6 & 34,428 & $-4,367$ & $-13,814$ & 6,861 & ,043 \\
\hline \multicolumn{7}{|c|}{ a. Method: Enter } \\
\hline \multicolumn{7}{|c|}{ b. Constant is included in the model. } \\
\hline \multicolumn{7}{|c|}{ c. Initial -2 Log Likelihood: 47,092 } \\
\hline \multicolumn{7}{|c|}{$\begin{array}{l}\text { d. Estimation terminated at iteration number } 6 \text { because parameter estimates changed by less } \\
\text { than }, 001 \text {. }\end{array}$} \\
\hline
\end{tabular}

(Sumber: Output SPSS 25.00, 2019)

Menilai model fit dapat dilihat dari nilai statistik -2LogLikelihood yaitu tanpa variabel hanya konstanta saja sebesar 35,488 setelah dimasukkannya 3 variabel baru maka nilai -2LogLikelihood turun menjadi 34,431 dan setelah semua variabel dimasukkan menjadi 34,428 atau dengan kata lain terjadi penurunan sebesar 1,06. Ini menunjukkan model fit.

4.3. Uji Koefisien Determinasi $\left(\mathrm{R}^{2}\right)$

Tabel 8 Hasil Uji Nagelkerke R Square

\begin{tabular}{|l|l|l|l|}
\hline \multicolumn{4}{|c|}{ Model Summary } \\
\hline Step & -2 Log likelihood & Cox \& Snell R Square & Nagelkerke R Square \\
\hline
\end{tabular}




\begin{tabular}{|c|c|c|c|}
\hline 1 & $34,428^{a}$ & 297 & ,406 \\
\hline \multicolumn{4}{|c|}{$\begin{array}{l}\text { a. Estimation terminated at iteration number } 6 \text { because parameter estimates changed } \\
\text { by less than }, 001 \text {. }\end{array}$} \\
\hline
\end{tabular}

(Sumber: Output SPSS 25.00, 2019)

Setelah menilai keseluruhan model (overall model fit) regresi, maka langkah selanjutnya adalah pengujian koefisien determinasi dengan melihat nilai Nakelkerke $R$ Square. Nilai Nakelkerke $R$ Square $\left(\mathrm{R}^{2}\right)$ diperoleh sebesar 0,406, hal ini menunjukkan bahwa income smoothing dapat dijelaskan sebesar 40,6 persen oleh variabel independen yaitu profitabilitas, leverage serta ukuran perusahaan sebagai variabel independen. Sedangkan sisanya sebesar 59,4 persen diterangkan oleh variabel lain yang tidak diteliti dalam model regresi logistik ini.

4.4. Uji Regresi Logistik

Tabel 9 Hasil Uji Wald

\begin{tabular}{|c|c|c|c|c|c|c|c|c|c|}
\hline \multicolumn{10}{|c|}{ Variables in the Equation } \\
\hline & & \multirow[b]{2}{*}{$\mathrm{B}$} & \multirow[b]{2}{*}{ S.E. } & \multirow[b]{2}{*}{ Wald } & \multirow[b]{2}{*}{$\mathrm{df}$} & \multirow[b]{2}{*}{ Sig. } & \multirow[b]{2}{*}{$\operatorname{Exp}(B)$} & \multicolumn{2}{|c|}{ 95\% C.I.for $\operatorname{EXP}(B)$} \\
\hline & & & & & & & & Lower & Upper \\
\hline \multirow{4}{*}{$\begin{array}{l}\text { Step } \\
1^{\text {a }}\end{array}$} & ROA & $-13,814$ & 16,012 & ,744 & 1 & ,388 &, 000 & ,000 & 42656390,225 \\
\hline & DR & 6,861 & 3,405 & 4,060 & 1 & 044 & 954,514 & 1,206 & 755435,603 \\
\hline & LNASET & ,043 & ,091 & ,225 & 1 & 635 & 1,044 & 874 & 1,248 \\
\hline & Constant & $-4,367$ & 2,814 & 2,408 & 1 & 121 & ,013 & & \\
\hline
\end{tabular}

Hasil dari uji wald, nilai eksponen $(\beta)$ dari koefisien persamaan regresi logistik menghasilkan persamaan regresi berikut ini:

Ln $(\mathrm{P} / 1-\mathrm{P})=-4,367-13,814 \mathrm{ROA}+6,861 \mathrm{DR}+0,043$
LNASET

Constant : $-4,367$. Artinya tanpa adanya pengaruh dari variabel profitabilitas, leverage, dan ukuran perusahaan, maka tindakan income smoothing akan bertambah sebesar 0,013.

ROA : $-13,814$. Artinya tindakan income smoothing tidak akan bertambah dan berkurang $(0,000)$ atau perusahaan tidak akan melakukan income smoothing.

DR : 6,861. Artinya tindakan income smoothing akan meningkat sebesar 954,514.

LNASET: 0,043. Artinya tindakan income smoothing akan meningkat sebesar 1,044 . 
Hasil dari uji hipotesis paramater individual (Uji Wald) dijelaskan secara rinci berikut ini:

H1: Profitabilitas berpengaruh signifikan terhadap Income Smoothing

Hasil Perhitungan:

Nilai Wald $=0,744$; dengan sig. $=0,388$

Variabel profitabilitas (ROA) memiliki nilai wald sebesar 0,744 dengan tingkat signifikansi lebih besar dari $\alpha 5 \%$, yaitu 0,388. Hal ini menunjukkan bahwa profitabilitas tidak terbukti berpengaruh secara signifikan terhadap Income Smoothing. Dengan demikian, hipotesis pertama $\left(\mathrm{H}_{1}\right)$ yang menyatakan bahwa Profitabilitas berpengaruh signifikan terhadap Income Smoothing menjadi Ditolak.

H2: Leverage berpengaruh signifikan terhadap Income Smoothing

Hasil Perhitungan:

Nilai Wald = 4,060; dengan sig. $=0,044$

Variabel leverage (DR) memiliki nilai wald sebesar 4,060 dengan tingkat signifikansi lebih kecil dari $\alpha 5 \%$, yaitu 0,044. Hal ini menunjukkan bahwa leverage terbukti berpengaruh secara signifikan terhadap Income Smoothing. Dengan demikian, hipotesis kedua $\left(\mathrm{H}_{2}\right)$ yang menyatakan bahwa leverage berpengaruh signifikan terhadap Income Smoothing Diterima.

H3: Ukuran Perusahaan berpengaruh signifikan terhadap Income Smoothing

Hasil Perhitungan:

Nilai Wald = 0,225; dengan sig. $=0,635$

Variabel ukuran perusahaan (LNASET) memiliki nilai wald sebesar 0,225 dengan tingkat signifikansi lebih besar dari $\alpha 5 \%$, yaitu 0,635 . Hal ini menunjukkan bahwa ukuran perusahaan tidak terbukti berpengaruh secara signifikan terhadap Income Smoothing. Dengan demikian, hipotesis ketiga $\left(\mathrm{H}_{3}\right)$ yang menyatakan bahwa ukuran perusahaan berpengaruh signifikan terhadap Income Smoothing menjadi Ditolak.

\subsection{Pembahasan}

Profitabilitas yang tinggi menunjukkan bahwa kinerja suatu perusahaan itu baik, sedangkan tingkat profitabilitas yang rendah dapat mengindikasikan bahwa kinerja suatu perusahaan itu buruk. Perusahaan dengan tingkat profitabilitas yang rendah cenderung akan melakukan income smoothing. Temuan ini menandakan bahwa besar atau kecilnya profitabilitas yang dihasilkan tidak menjadi jaminan manajer akan mengambil kebijakan menggambarkan keadaan perusahaan dalam kondisi yang sehat dan menghindari pelaporan laba yang berfluktuasi atau sebaliknya. Penelitian ini sejalan dengan temuan tidak berpengaruhnya profitabilitas terhadap income smoothing disebabkan oleh nilai aset 
perusahaan yang relatif optimal. Oleh sebab itu, manajemen tidak memilih melakukan income smoothing menggunakan laba sebagai alat untuk melakukan income smoothing sebab rentan teranalisis oleh pihak luar (Marhamah, 2016; Pradana \& Sunaryo, 2012). Temuan penelitian ini juga bertolak belakang dengan temuan profitabilitas (ROE) berpengaruh negatif terhadap Perataan laba (Handayani \& Fuad, 2015).

Leverage berpengaruh positif terhadap income smoothing dengan nilai koefisien positif sebesar 6,861 dengan tingkat signifikansi sebesar 0,044. Leverage menunjukkan proporsi penggunaan utang untuk pembiayaan aset. Perusahaan yang memiliki leverage tinggi, dapat membuat pihak eksternal tidak percaya terhadap perusahaan tersebut sehingga agar pihak eksternal percaya terhadap perusahaan, maka perusahaan harus bisa mengimbangi antara hutang dan laba yang diterima oleh perusahaan. Penelitian ini sejalan dengan temuan dengan istilah yang sering digunakan untuk mengukur kemampuan suatu perusahaan dalam memenuhi seluruh kewajiban financialnya. Semakin tinggi leverage maka semakin besar risiko yang ditanggung oleh perusahaan untuk itu perusahaan akan melakukan perataan laba (Herlina, 2017). Temuan penelitian ini juga bertolak belakang dengan temuan leverage yang tidak membuktikan adanya praktik perataan laba, kondisi ini menyebabkan investor dan kreditur takut untuk berinvestasi atau meminjamkan dananya kepada perusahaan sehingga menimbulkan keinginan manajemen untuk melakukan praktik perataan laba (Marhamah, 2016).

Ukuran perusahaan yang lebih besar memiliki motivasi yang lebih besar pula untuk melakukan income smoothing dibandingkan dengan perusahaan-perusahaan yang lebih kecil sebab perusahaan-perusahaan yang lebih besar menjadi subjek pemeriksaan (pengawasan yang lebih ketat dari pemerintah dan masyarakat umum/general public). Penelitian ini sejalan dengan temuan tidak berpengaruhnya ukuran perusahaan terhadap income smoothing (Pradana \& Sunaryo, 2012; Marhamah, 2016), hal ini disebabkan oleh perbedaan peraturan pemerintah negara maju dengan peraturan negara berkembang yang berkaitan dengan biaya politik (polical cost) dan pembebanan pajak. Di negara maju, pemerintah membebankan biaya politik terhadap perusahaan sehingga semakin besar perusahaan, maka semakin besar pula biaya politis yang harus ditanggungnya sementara temuan penelitian ini bertolak belakang dengan temuan ukuran perusahaan berpengaruh signifikan terhadap income smoothing (Herlina, 2017; Siti Masyithoh, 2017).

\section{Kesimpulan dan Saran}

Berdasarkan hasil data dan pembahasan dapat disimpulkan bahwa profitabilitas dan ukuran perusahaan tidak berpengaruh signifikan terhadap income smoothing sementara leverage berpengaruh positif dan signifikan terhadap income smoothing. Peneliti selanjutnya diharapkan mengevaluasi pengukuran profitabiltias lainnya dengan proksi lainnya 29|Jurnal Buana Akuntans i 
seperti ROE, ROI atau NPV agar dapat memperbaiki hasil penelitian ini yang tidak berpengaruh signifikan. Perusahaan dapat melibatkan sampel perusahaan yang lebih banyak, rentang waktu yang lebih lama agar diperoleh hasil pengujian yang lebih akurat dan menambahkan atau menggunakan variabel lain sebagai variabel independen untuk mengetahui bagaimana pengaruhnya terhadap income smoothing serta menggunakan indeks selain Indeks Eckel.

\section{Daftar Pustaka}

Afrianto, D. (2016, Januari 27). Direksi Timah Dituding Manipulasi Laporan Keuangan. Dipetik Agustus 23, 2019, dari OK Finance: https:/ / economy.okezone.com/read/2016/ 01/27/278/1298264/direksi-timahdituding-manipulasi-laporan-keuangan

Damayanti, A., Ambarwati, S., \& Susilawati. (2019). Pengaruh Perputaran Persediaan Dan Leverage Terhadap Profitabilitas Wholesale And Retail Trade Di BEI. Mpu Procuratio : Jurnal Penelitian Manajemen, 1 (2), 194-210.

Dikky Setiawan. (2016, Agustus 4). Semester I, Portofolio investasi SRTG tumbuh 26\%. (D. Setiawan, Penyunting) Dipetik Agustus 23, 2019, dari https://investasi.kontan.co.id/: https://investasi.kontan.co.id/news/semester-iportofolio-investasi-srtg-tumbuh-26

Handayani, F., \& Fuad. (2015). Faktor Yang Berpengaruh Terhadap Perataan Laba. Diponegoro Journal of Accounting, 4 (2), 1-12.

Hardaningtyas, R. T., \& Siswoyo, B. B. (2016). Pengaruh Kebijakan Dividen dan Corporate Social Responsibility (CSR) terhadap Return Saham pada Perusahaan LQ 45 periode 2015. Jurnal Pendidikan: Teori, Penelitian, dan Pengembangan, 1 (4), 574582.

Hastria, D., Rasuli, M., \& Nurazlina. (2014). Pengaruh Ukuran Perusahaan, Financial Leverage, Dividen Payout Ratio dan Net ProfitMargin terhadap Tindakan Perataan Laba yang Dilakukan oleh Perusahaan Automotive and Allied Product yang Listing di BEI. Jur. Jurnal Akuntansi Universitas Riau, 1 (1), 1-15.

Herlina, S. (2017). Pengaruh Ukuran Perusahaan, Financial Leverage, NetProfit Margin Dan Struktur Kepemilikan Terhadap Tindakan Perataan Laba Pada PerusahaanManufakturyang Terdaftar Di BEI Periode 2011-2014. JOM Fekon, 4 (1), 601-613.

Hery. (2016). Analisis Kinerja Manajemen (Cetakan Kedua). Jakarta: PT Grasindo. Hery. (2014). Pengendalian Akuntansi dan Manajemen. Jakarta: Penerbit Kencana. Kasmir, D. (2016). Analisis Laporan Keuangan. Jakarta: PT. Rajagrafindo Persada. Kurniawan, R., \& Yuniarto, B. (2016). Analisis Regresi. Jakarta: Penerbit Kencana. Marhamah. (2016). Pengaruh Profitabilitas, Net Profit Margin, Leverage, Ukuran Perusahaan, dan Reputasi Auditor Terhadap Perataan Laba. Jurnal STIE Semarang, 8 (3), 103-122.

Musdholifah, \& Puspitasari, D. (2009). Pengaruh Ukuran Perusahaan, Profitabilitas dan Leverage terhadap Perataan Laba pada Sektor Industri Perbankan. Jurnal Bisnis dan Manajemen (BISMA), 2 (1), 48-60.

Pradana, A. W., \& Sunaryo. (2012). Analisis Pengaruh Company Size, Return On Assets, Financial Leverage, Dan Operating Leverage Terhadap Income Smoothing 
Practices Pada Perusahaan Manufaktur Yang Terdaftar Di Bursa Efek Indonesia. BINUS Business Review, 3 (1), 131-140.

Prasidhanto, W. (2012). Studi Biaya Tenaga Kerja Badan Usaha Milik Negara (BUMN): Kontribusi Pegawai dan Eksekutif Terhadap Kinerja Perusahaan. Jurnal Riset E Informasi (Membangun Kebijakan Berbasis Analisa), IV.

Sekaran, U., \& Bougie, R. (2017). Metode Penelitian untuk Bisnis Pendekatan Pengembangan-Keahlian (6 ed.). Jakarta: Salemba Empat.

Siti Masyithoh. (2017). Tindakan Perataan Laba pada Perusahaan Perbankan. Jurnal Aplikasi Manajemen, Ekonomi dan Bisnis, 1 (2), 104-119.

Sugianto, D. (2019, April 25). Garuda Diduga Manipulasi Laporan Keuangan, Bagaimana Pengawasan Rini? Dipetik Agustus 23, 2019, dari https:/ / finance.detik.com/bursa-dan-valas/d-4524789/garuda-diduga-

manipulasi-laporan-keuangan-bagaimana-pengawasan-rini

Sulistyanto, S. (2014). Manajemen Laba Teori dan Modal Empiris. Jakarta: Penerbit Grasindo.

Supriastuti, S., \& Warnanti, A. (2015). Ukuran Perusahaan, Winner/Loser Stock, Debt ToEquity Ratio, Dividend Payout Ratio Pengaruh Terhadap Perataan Laba. Jurnal Paradigma, 13 (01), 45-62.

UU. (2008). Undang-Undang Nomor 20 Tahun 2008.

Yanti. (2018). Analisa Pengaruh Faktor-Faktor Pembentuk Fee Ijarah (PSAK 107)

Terhadap Portofolio Rahn Emas Di Bank Syariah. Jurnal Buana Akuntansi, 3 (1). 